\title{
Indonesia sebagai Kekuatan Menengah: Komparasi Respon Indonesia terhadap Illegal Fishing dan Laut Tiongkok Selatan
}

\author{
Kezya Agustina Hananya \& Fitra Shaumi Azzahra \\ Universitas Airlangga
}

\begin{abstract}
Abstrak
Dihadapkan pada kondisi internasional yang condong ke arah anarki, lingkungan internasional memiliki klasifikasi tersendiri yang didasarkan pada pengaruh politik negara dan kemampuan nasional. Klasifikasi tersebut terdiri dari negara-negara gagal, berkekuatan kecil, berkekuatan menengah, regional, berkekuatan besar, dan adikuasa. Berdasarkan penilaian kemampuan nasional dan perbandingan dengan negara lain, Indonesia dapat diklasifikasikan sebagai negara kekuatan menengah. Hal ini dapat dibuktikan dari tanggapan Indonesia terhadap dua isu berbeda, yaitu penangkapan ikan ilegal dan klaim Tiongkok di bagian utara Pulau Natuna. Kedua tantangan ini mengandung beberapa kesamaan, namun membangkitkan berbagai tanggapan dari Indonesia. Sementara Indonesia menunjukkan tindakan berani terhadap pelaku penangkapan ikan ilegal dari negara-negara Asia Tenggara, Indonesia tidak menunjukkan tindakan yang sama terhadap Tiongkok. Kenyataannya, Indonesia cenderung tidak jelas dan memilih untuk berada di tengah masalah daripada terlibat dalam konflik. Tujuan dari artikel ini adalah untuk membuktikan bahwa tesis Breuning tentang tingkat analisis sistemik internasional juga berlaku dalam konteks ini.
\end{abstract}

Kata-kata kunci: kebijakan luar negeri, penangkapan ikan ilegal, poros maritim, kekuatan menengah, Laut Tiongkok Selatan

Faced with international condition that inclines toward anarchy, international environment has its own classification that is based on states' political influence and national capabilities. The classification consists of failed states, small power, middle power, regional, great power, and superpower. Based on the assessment of national capability and comparison with other countries, Indonesia can be classified as a middle power country. This can be proven from Indonesia's response towards two different issues, namely illegal fishing and China's claim on the northern part of Natuna Island. These two challenges contain some similarities, yet evoke different responses from Indonesia. While Indonesia shows its bold actions towards illegal fishing from Southeast Asian countries, it does not show the same action towards China. In fact, Indonesia tends to be unclear and stand in the middle of the problem instead of engaging in the conflict. The objective of this article is to prove that Breuning's thesis on international systemic level of analysis also applies in this context.

Keywords: foreign policy, illegal fishing, maritime axis, middle power, South China Sea. 
Presiden Indonesia Joko Widodo (Jokowi) adalah presiden yang memberikan perhatian khusus terhadap dunia maritim. Hal ini dapat diamati dari pidato pelantikannya pada 20 Oktober 2014 yang secara spesifik menyinggung visinya untuk memperkuat Indonesia dalam bidang maritim. Visi tersebut tercermin melalui kutipan pidato Jokowi yang berbunyi "kita telah lama memunggungi samudra, laut, selat, dan teluk. Maka, mulai hari ini, kita kembalikan kejayaan nenek moyang sebagai pelaut pemberani. Menghadapi badai dan gelombang di atas kapal bernama Republik Indonesia." (Nurhasim, 2014). Jokowi menekankan bahwa sudah waktunya bangsa Indonesia menyadari jalesveva jayamahe (Di lautan kita jaya) yang merupakan moto nenek moyang Indonesia di masa lalu (Setiawan, 2014). Dengan visi tersebut, Jokowi segera mendorong penyelesaian masalah-masalah yang berkaitan dengan kelautan Indonesia. Salah satu masalah klasik kelautan dan perikanan Indonesia adalah permasalahan penangkapan ikan ilegal. Bahaya dari penangkapan ikan ilegal ini juga telah ditekankan oleh Food and Agricultural Organization (FAO). Menurut FAO (2014), kerugian meyeluruh Indonesia akibat penangkapan ikan ilegal diperkirakan mencapai 30 triliun Rupiah per tahun. Namun, hal yang berbeda diungkapkan oleh Jokowi dan Menteri Kelautan dan Perikanan Indonesia yaitu Susi Pudjiastuti. Menurut Jokowi, penangkapan ikan ilegal yang dilakukan oleh pihak asing tersebut membawa kerugian bagi Indonesia sebanyak kurang lebih 240 triliun Rupiah per tahunnya. Hal yang sama juga diungkapkan oleh Susi Pudjiastuti. Ia menganggap angka yang diberikan FAO terlalu kecil dan apabila dihitung secara rinci, maka Indonesia setidaknya merugi paling sedikit 12,5 miliar Dolar AS dan paling banyak 20 miliar Dolar AS (detikFinance, 2014).

\section{Perbedaan Respon Indonesia dalam Menanggapi Penangkapan Ikan Ilegal dan Kehadiran Tiongkok di Laut Natuna}

Menjawab pelanggaran-pelanggaran yang merugikan tersebut, Jokowi segera melakukan tindakan lebih lanjut yaitu dengan menenggelamkan kapal ilegal. Dalam sebuah pertemuan Lembaga Pertahanan Nasional Republik Indonesia (Lemhannas RI), Jokowi dengan tegas menyatakan "There is no need to arrest them [the illegal fishing boats]; just sink them," (Widhiarto, 2014). Dikutip oleh Kuwado (2017), jumlah kapal yang telah ditenggelamkan sejak Oktober 
2014 sampai dengan 1 April 2017 adalah 317 kapal dengan rincian sebagai berikut: Vietnam 142 kapal, Filipina 76 kapal, Thailand 21 kapal, Malaysia 49 kapal, Indonesia 21 kapal, Papua Nugini 2 kapal, Tiongkok 1 kapal, Belize 1 kapal, dan tanpa negara 4 kapal. Dari data ini, dapat kita ketahui bahwa banyak penangkapan ikan ilegal dilakukan oleh pihak asing yang menggunakan bendera negaranya. Beberapa dari mereka memang tidak memiliki hubungan dengan aktor negara secara langsung, namun setelah ditelisik ulang, sebagian dari mereka sempat melancarkan prosesi 'fish laundering' dimana hal tersebut melibatkan aktor negara. Perbuatan tersebut dianggap merugikan Indonesia sehingga Indonesia memilih untuk menindak tegas kapal tersebut dengan menenggelamkan dan melakukan perusakan total. Menurut Menteri Kelautan, Susi Pudjiastuti, hal tersebut dilakukan untuk memunculkan 'deterrent effect' bagi kapal pemancing ilegal tersebut (Parameswaran, 2017).

Selain permasalahan penangkapan ikan ilegal, Indonesia dihadapkan pada satu permasalahan kelautan yang krusial. Hal ini mengenai perairan sekitar Pulau Natuna di barat daya Kalimantan yang termasuk dalam Zona Ekonomi Eksklusif (ZEE) Indonesia dan tumpang tindih dengan klaim teritori Tiongkok di Laut Cina Selatan (LCS) yang kemudian dikenal sebagai sembilan garis putus-putus atau 'nine-dash lines'. Sembilan garis tersebut adalah garis batas pemisah yang digunakan Tiongkok untuk mengklaim sebagian besar wilayah LCS yang masih menjadi sengketa sejumlah negara-negara di Asia (Kusumadewi, 2016). Kontestasi antara kedua negara bermula pada bulan Juni 2016 ketika kapal Tiongkok memasuki perairan Natuna yang merupakan bagian ZEE Indonesia. Menurut Edi Sucipto, Kepala Dinas Penerangan Tentara Nasional Indonesia Angkatan Laut (TNI AL), penangkapan terhadap kapal Tiongkok tersebut bermula ketika Kapal Perang (KRI) Imam Bonjol 383 berpatroli di sekitar Natuna dan menerima informasi bahwa terdapat 12 kapal memancing secara ilegal di perairan Natuna (Kusumadewi, 2016). KRI Imam Bonjol memburu kapal-kapal tersebut dan melepas tembakan peringatan. Tembakan tersebut merusak kapal milik Tiongkok, melukai satu anggota nelayan, dan tujuh orang ditahan di Indonesia (Hua, 2016).

Sedangkan menurut Tiongkok, kapal-kapal milik mereka sedang beroperasi secara normal pada wilayah perairan tradisional Tiongkok. Ketika Tiongkok mengetahui bahwa Indonesia telah 
menembak kapalnya, Tiongkok segera mengerahkan kapal-kapal penjaga pantai yang beroperasi di sekitar lokasi tersebut untuk melindungi kapal penangkap ikan lainnya dan menyelamatkan yang terluka (Hua, 2016). Tiongkok menegaskan tiga klaim utama mengenai kejadian ini. Pertama, kejadian ini terjadi di perairan yang merupakan kawasan penangkapan ikan tradisional bagi Tiongkok. Kedua, Indonesia dan Tiongkok memiliki klaim yang tumpang tindih terhadap kepentingan dan hak maritim. Ketiga, Indonesia melanggar hukum-hukum internasional seperti United Convention on the Law of the Sea (UNCLOS) dan Declaration on the Conduct of Parties in South China Sea (DOC). Tiongkok mendorong Indonesia untuk berhenti melakukan tindakan yang dapat menyulitkan kedua belah pihak, membesar-besarkan perselisihan, merusak perdamaian dan stabilitas, dan menangani masalah perikanan di laut secara konstruktif (Hua, 2016).

Indonesia membantah seluruh klaim yang ditegaskan oleh Tiongkok dengan mengatakan bahwa Pulau Natuna adalah wilayah kedaulatan Indonesia. Menteri Luar Negeri Indonesia, Retno Marsudi, mengatakan bahwa hal tersebut sudah tidak dapat diganggu gugat. Beliau menjelaskan bahwa bagian terluar dari Pulau Natuna adala baseline dari teritori Indonesia seperti yang tertulis pada Deklarasi Juanda tahun 1957. Lebih lanjut, mengacu pada UNCLOS pada tahun 1982, baseline tersebut telah didaftarkan kepada Perserikatan Bangsa-Bangsa (PBB) pada tahun 2009 (Antara News, 2016). Menurut Indonesia, klaim Tiongkok atas kawasan penangkapan ikan tradisional tersebut tidak dapat dibenarkan karena wilayah tersebut mutlak milik Indonesia (Kusumadewi, 2016).

Alih-alih melakukan klaim seperti negara ASEAN yang lain, hal yang kemudian dilakukan oleh Indonesia adalah mengubah nama perairan bagian utara Natuna yang masuk ke dalam kategori ZEE Indonesia. Indonesia mengubah nama perairan tersebut menjadi Laut Natuna Utara (Pratomo, 2017). Menurut Deputi Kedaulatan Maritim, Arif Havas Oegroseno, hal ini dilakukan karena sejumlah kegiatan pengelolaan minyak dan gas di wilayah Natuna memiliki nama proyek yang berbeda-beda. Lebih lanjut lagi, beliau mengatakan bahwa Indonesia memiliki kewenangan untuk melakukan pergantian nama di wilayah teritorial Indonesia (Pratomo, 2017). Tiongkok mengecam pergantian nama ini dengan 
menagatakan bahwa pergantian tersebut tidak masuk akal serta tidak konduktif terhadap standarisasi internasional atas nama tempat (Luu et al, 2017). Namun tidak terdapat tindakan lanjut dari kedua belah pihak mengenai klaim atas perairan Natuna ini walau hingga saat ini dapat dipastikan bahwa masih terdapat kapal pemancing Tiongkok yang beredar pada perairan Natuna yang ditemani oleh kapal Induk dari Tiongkok sendiri. Kapal dari Indonesia pun masih melakukan patroli seperti biasanya namun tidak melakukan tindak lanjut yang serius terhadap aktivitas yang berlangsung pada perairan Natuna (Luu et al, 2017).

Dari paparan diatas dapat dilihat bahwa terdapat dua aktivitas serupa yang terjadi pada wilayah dan aktor yang dinaungi oleh negara yang berbeda. Namun kebijakan yang dikeluarkan oleh Indonesia terhadap keduanya memiliki distingsi yang jauh berbeda. Indonesia yang secara jelas membasmi kapal dengan bendera negara-negara seperti Filipina, Vietnam, Thailand dan lainnya sedangkan penenggelaman tersebut tidak benar-benar dilakukan oleh Indonesia terhadap Tiongkok di perairan Natuna. Penulis berargumen bahwa posisi Indonesia yang pada saat ini mulai dikenal sebagai middle power di lingkungan internasional memiliki pengaruh pada pola perilaku serta kebijakan yang dikeluarkan oleh Indonesia. Adanya status yang disandang tersebut memiliki signifikansi untuk menjadi pertimbangan para pengambil keputusan di Indonesia. Selanjutnya, penulis akan memaparkan mengenai teori International Systemic Level of Analysis yang akan digunakan sebagai alat analisis bagi kebijakan yang telah dipaparkan di atas.

\section{Peringkat Analisis Sistem Internasional}

Menurut Breuning (2007), lingkungan internasional merupakan tempat yang memiliki tingkatan tertentu, meskipun tidak terlihat. Kebijakan yang hendak dirancang oleh para pengambil keputusan memiliki signifikansi dalam memosisikan suatu negara pada tingkatan tersebut. Di sisi lain, dapat diketahui bahwa negara pun memiliki kapabilitas internal yang memiliki peran dalam memosisikan suatu negara dalam tingakatan itu. Dalam kondisi tertentu, kapabilitas internal merupakan penentu utama posisi negara dalam pengklasifikasian yang ada dalam lingkungan internasional (Breuning, 2007). Kapabilitas yang berbeda dapat 
dilihat dari bentuk dan ukuran negara. Negara yang memiliki wilayah darat yang kecil dan terhimpit oleh negara besar lainnya cenderung memiliki keterbatasan dalam mengeluarkan kebijakan kontroversial, karena rentan serangan force dimana negara kecil biasanya tidak memiliki kekuatan militer yang sebanding dengan negara besar (Shaohua, 2015). Indikator lain dapat dilihat dari negara kecil maupun besar secara ukuran namun memiliki sumber daya yang melimpah, maka opsi dalam kebijakannya bergantung pada kemampuan suatu negara ini dalam mengelola sumber dayanya (Shaohua, 2015).

Breuning (2007) memandang bahwa pengambil keputusan di suatu negara harus memiliki kemampuan dalam melihat dinamika lingkungan internasional dan mempertimbangkannya sedemikian rupa dalam proses perumusan kebijakan. Hal ini merupakan suatu yang rumit karena selama ini tidak ada indikator yang jelas bagi suatu negara dalam menempati struktur atau sistem internasional, karena pada dasarnya politik internasional tidak sama dengan politik domestik negara yang memiliki entitas legal yang mampu menstrukturkan dan memberikan fungsi atas struktur dalam suatu negara. Namun terdapat beberapa hal yang dapat dijadikan acuan dalam melihat siapa yang lebih berpengaruh dalam lingkungan tersebut. Yang pertama yakni melihat kekuatan dan kapabilitas internal negara. Hal ini berkaitan erat dengan kekuatan nasional yang tangible maupun intangible, seperti ukuran negara, sumber daya yang dimiliki, kapabilitas negara dalam mengolah sumber daya tersebut, perekonomian negara, jumlah penduduk, dan kekuatan militer. Kedua, kemampuan 'leadership' negara dalam mengasumsikan kekuatan negara lain dalam satu lingkungan politik internasional yang sama. Dalam hal ini pemegang keputusan yang berada di posisi atas negara harus dapat melihat apa yang dimiliki oleh negaranya dan apa yang dimiliki oleh negara lain dan membandingkannya. Di samping itu, para decision maker juga harus dapat melihat peluang potensi negara serta tekanan eksternal dan internal negara yang harus diakomodasi dalam pengambilan keputusan (Breuning 2007). Ketiga, melihat ada tidaknya suatu peristiwa, tuntutan, atau pernyataan tertentu dari pihak eksternal yang dirasa cukup kuat sehingga dapat dipertimbangkan sebagai sebuah tuntutan yang harus dapat dipenuhi agar suatu negara dapat mencapai kepentingan, atau paling tidak, keamanan negaranya (Breuning, 2007). 
Guna memudahkan proses analisis, perlu dilakukan penentuan kondisi lingkungan internasional serta memetakan klasifikasi yang ada pada sistem dalam lingkungan internasional tersebut. Putnam (1998) memercayai bahwa lingkungan internasional pada dasarnya bersifat anarkis dimana negara besar maupun kecil akan berlombalomba mendapatkan power guna mempertahankan negaranya dalam sistem internasional. Walau begitu power yang didapatkan oleh negara-negara ini memunculkan klasifikasi secara hirarkis dimana mereka yang memiliki power lebih akan mendapat opsi yang lebih banyak dalam menentukan arah politik internasional.

Terdapat setidaknya lima klasifikasi negara secara umum, yakni failed state, small power, middle power, regional atau great powers serta superpower. Pengklasifikasian ini didapatkan dari peranan yang dimainkan oleh negara dalam politik internasional bersamaan dengan kekuatan objektif yang dimiliki terhadap negara lainnya (Breuning, 2007). Failed state yakni negara yang memiliki negara dengan institusi internal pemerintahan yang sangat lemah. Small states yakni negara yang memiliki pemerintahan cukup baik, namun memiliki kapabilitas rendah dan kemampuan mengelola sumber daya yang sangat lemah sehingga negara masih rentan dengan ancaman stabilitas internal. Selanjutnya, middle power yakni negara dengan pemerintahan yang cukup baik, sumber daya yang cukup baik dan sudah mulai mampu memberi pengaruh yang berarti dalam lingkungan serta perpolitikan internasional. Negara-negara middle power dapat dicontohkan oleh negara yang termasuk dalam G-20. Regional power adalah mereka yang paling berpengaruh pada regional mereka dan membuat mereka lebih memiliki opsi kebijakan yang luas, karena dipertimbangkan sebagai 'perwakilan' dari regional tertentu. Selanjutnya yakni great power, yaitu negara dengan sistem pemerintahan yang konsisten dan terstruktur rapi, tingkat perekonomian yang baik dan tinggi, serta memiliki signifikansi yang tinggi dalam lingkungan internasional. Memiliki opsi yang cukup luas dalam menentukan kebijakan luar negeri yang akan dirumuskannya dan memiliki pengaruh yang besar dalam perpolitikan internasional. Yang terakhir yakni superpower yang biasanya pada zaman ini merujuk pada Amerika Serikat sebagai pemenang Perang Dingin dan menjadi pihak yang sangat berpengaruh dalam politik internasional dimana negara-negara lain terus menyesuaikan diri dengan dinamika yang dilontarkan oleh negara tersebut (Breuning, 2007). 


\section{Posisi Indonesia sebagai Middle Power dalam Sistem Internasional}

Merujuk pada kedua pemaparan fenomena dan teori tersebut, terdapat beberapa hal yang dapat diamati. Pertama, dapat kita lihat bahwa Indonesia dalam kategorisasi yang dipaparkan oleh Breuning termasuk dalam negara middle power. Hal tersebut dapat dilihat dari beberapa sisi. Pertama, kapabilitas negara. Indonesia dihitung sejak tahun 2013 menjadi negara dengan kekuatan ekonomi 16 terbesar di dunia (Santikajaya, 2013). Struktur pemerintahan Indonesia masih dinilai stabil dan mampu untuk menjalankan fungsi kenegaraannya. Indonesia juga dinilai sebagai negara yang aktif dalam perpolitikan internasional, sebagaimana terlihat dalam partisipasinya di organisasi dan forum-forum internasional. Sebagaimana yang telah dipaparkan di atas, dilihat dari aspek kelautan dan kemaritiman Indonesia merupakan negara yang diberikan kapabilitas geografis yang strategis karena menjadi titik pelabuhan dua samudera yang jelas pada akhirnya disadari oleh Presiden Joko Widodo. Namun, walau Indonesia menyandang status middle power, pilihan akan kebijakan yang dikeluarkan masih terbatas. Hal ini karena dalam sistem regional ASEAN, kekuatan Indonesia dalam perihal ekonomi masih terkalahkan oleh negara-negara seperti Singapura, Malaysia dan Thailand. Indonesia juga tidak memiliki superioritas militer pada tingkat regional sehingga tidak benar-benar memberikan paksaan pada pihak manapun secara regional. Selanjutnya, salah satu permasalahan yang menjadi pertimbangan Indonesia adalah politik domestik Indonesia yang tersekat pada nilai dan identitas yang berbeda beda (Santikajaya, 2013). Hal ini juga yang membuat Indonesia harus memfokuskan pertahanan internal negara terlebih dahulu sebelum mengembangkan kekuatan militernya untuk sepenuhnya memiliki pengaruh dalam level regional. Dalam pemaparan ini dapat kita pahami bahwa Indonesia merupakan negara middle power yang masih berupaya untuk mencapai peranperannya sebagai middle power. Dalam kata lain, Indonesia masih belum dapat mengoptimalisasikan fungsinya sebagai middle power secara regional. Oleh karena itu, untuk optimalisasi power-nya, dibutuhkan suatu kebijakan yang dapat menopang Indonesia untuk mengembangkan negaranya sebagai middle power yang memiliki opsi kebijakan yang lebih banyak. 


\section{Perbandingan Kapabilitas Indonesia dengan Tiongkok sebagai Pertimbangan Pengambilan Kebijakan}

Dalam hal ini dapat dipahami bahwa Joko Widodo sebagai seorang presiden memahami pentingnya mengeluarkan suatu kebijakan yang dapat mengamankan sekaligus mengembangkan statusnya sebagai negara yang memiliki kekuatan cukup dalam lingkungan internasional. Mengikuti pemahaman presiden Jokowi sebagai seorang individu yang memiliki ketertarikan pada aspek kelautan dan kemaritiman, ia melihat Indonesia sebagai negara yang memiliki potensi dalam hal itu dan optimalisasi Indonesia sebagai middle power dapat diwujudkan melalui hal tersebut. Hal ini jelas dipaparkan berulang kali oleh presiden dalam kampanyenya serta dalam pidatonya dalam forum seperti IMO dan IORA. Berangkat dari kepercayaan Joko Widodo tersebut, hal yang harus dilakukan selanjutnya adalah membuat kebijakan konkrit dan mengeksekusi kebijakan tersebut dengan mempertimbangkan status Indonesia sebagai middle power dengan cara merefleksikan kapabilitas Indonesia dan melakukan perbandingan dengan kapabilitas negara yang dihadapinya.

Kasus pertama yang dihadapi oleh Indonesia adalah penangkapan ikan ilegal. Pada kasus ini, Indonesia menjalankan fungsi Poros Maritimnya dengan mengamankan kedaulatan laut Indonesia. Dalam kasus ini, meski ada kritik dari Badan Ilmu Pengetahuan dan badan yudikatif (kejaksaan agung) mengenai kerugian penenggelaman kapal, namun tidak ada yang menahan Menteri Susi Pudjiastuti untuk melakukan hal tersebut (Tempo.co, 2014). Pengkritisi sendiri menyebut kebijakan ini terlalu 'berani' dan 'tegas' sehingga dapat memperburuk hubungan Indonesia dengan beberapa negara Asia Tenggara (Dharanindra, 2016). Hal ini disanggah oleh Susi Pudjiastuti dalam pernyataan berikut ini:

“Tidak ada yang harus dikhawatirkan akan penenggelaman ini. Pertama, hal ini memang ilegal secara hukum. Kedua, meski ada negara yang mengajukan protes, maka saya yakin mereka tidak akan benar-benar mengutarakan langsung pada kita karena memang tidak ada untungnya melakukan hal tersebut. Ketiga, di Asia Tenggara, Indonesia menjadi 'role model'. Beberapa saat setelah saya menerapkan kebijakan ini, negara-negara tetangga kita pun malah ingin meniru kebijakan kita ini" 
Dari kutipan tersebut, penggunaan kata 'role model' dapat kita asumsikan sebagai pernyataan bahwa Indonesia memiliki suatu kelebihan yang dapat memengaruhi negara-negara lain untuk mengikuti kebijakannya. Hal ini membuat Indonesia cukup berani dalam mengambil kebijakan yang tegas ini, karena memang pihak yang dihadapkannya memang bersalah dan negara yang terlibat dalam isu ini juga memiliki kapabilitas internal negara yang tidak jauh berbeda dengan Indonesia. Ketika Indonesia mengeluarkan kebijakan yang cukup keras, tidak banyak kerugian yang berarti bagi Indonesia. Setidaknya Indonesia masih memiliki banyak cara untuk menghadapi situasi tersebut.

Selain itu, keaktifan Indonesia dalam forum-forum internasional seperti IMO, IORA dan ASEAN membuat Indonesia cukup memiliki signifikansi dalam sistem internasional sehingga opsi kebijakan Indonesia setidaknya lebih luas dari beberapa negara Asia Tenggara lainnya. Walau Indonesia tidak memiliki superioritas militer secara regional secara prinsip, potensi militer nasional Indonesia masih menjadi yang pertama dalam region Asia Tenggara, dibandingkan Vietnam, Thailand, Malaysia, dan Filipina (Global Fire Index, 2017). Kekuatan ini tampaknya dipertimbangkan negara lain yang memiliki kapal ilegal sehingga tidak terdapat respons yang berarti dari pihak pemancing. Terlebih Indonesia sendiri tidak mendapat kecaman internasional yang berarti sehingga tidak benar-benar ada tuntutan untuk tidak menerapkan kebijakan tersebut.

Hal ini sedikit berbeda dengan kebijakan yang diambil Indonesia dalam kasus pulau Natuna yang terancam klaim 'nine dash lines' oleh Tiongkok. Walau Indonesia terlihat sangat gencar dalam membuktikan bahwa ia memiliki kekuatan TNI yang cukup kuat untuk menghadang ancaman eksternal, penulis berasumsi bahwa pembuktian tersebut hanya sebatas optimisme Indonesia terhadap visi Indonesia Maritime Axis secara keseluruhan. Nyatanya dalam kasus ini, Indonesia tidak pernah benar-benar memberi 'stance' yang jelas. Indonesia merupakan satu dari beberapa negara ASEAN yang tidak secara resmi menjadi 'claimant' atau pengklaim akan porsinya pada Laut Cina Selatan (Parameswaran, 2017). Hal ini mungkin dapat dijelaskan sebagai keraguan Indonesia dalam bertindak lebih agresif mengingat kapabilitas militernya yang berbeda jauh dari Tiongkok. Kapabilitas militer suatu negara dapat diukur melalui tiga hal, yaitu dana yang dikeluarkan setiap tahunnya untuk militer 
serta jumlah unit alutsista angkatan udara, laut, dan darat. Dikutip dari Global Fire Power (2017), Tiongkok menempati urutan ketiga militer terkuat di dunia dan Indonesia menempati urutan keempat belas. Gambar 1 adalah jumlah dana yang dialokasikan untuk pertahanan dan penguatan militer. Tiongkok menempati nomor 2 di dunia dengan angka 161,700,000,000 dolar Amerika Serikat pada tahun 2017. Sedangkan Indonesia menempati nomor 30 dengan USD 6,900,000,000 di tahun yang sama (Global Fire Power, 2017).

Kemudian, semakin tinggi jumlah alutsista yang dimiliki, maka militer suatu negara akan lebih kuat. Dikutip dari Global Fire Power (2017), jumlah kepemilikan alutsista angkatan laut Tiongkok lebih superior ketimbang Indonesia, seperti yang diilustrasikan di Gambar 2. Dari kepemilikan alutsista angkatan darat, Tiongkok juga masih lebih superior daripada Indonesia seperti yang dapat dilihat di Gambar 3. Terakhir, kepemilikan alutsista angkatan udara pada Gambar 4, Tiongkok juga masih lebih superior daripada Indonesia, seperti yang diukur dilihat melalui kepemilikan helikopter maupun aircraft lainnya yang berbeda jauh dari Indonesia.

Gambar 1. Perbandingan jumlah budget pertahanan Tiongkok dan Indonesia pada tahun 20

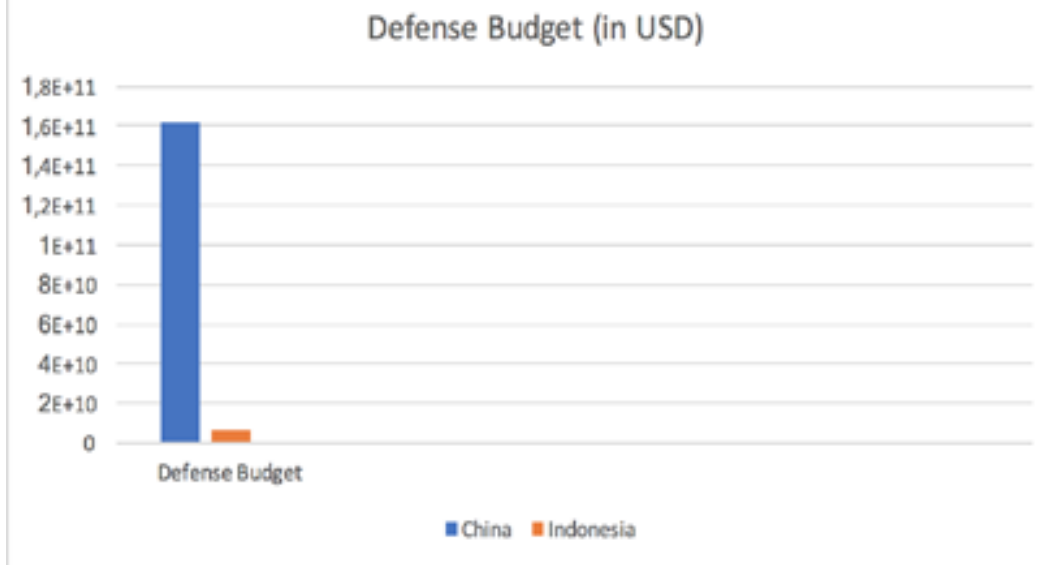

Figur 1. Perbandingan jumlah budget pertahanan Tiongkok dan Indonesia pada tahua 2017 -9 
Gambar 2. Perbandingan kepemilikan alutsista angkatan laut Tiongkok dan Indonesia (2017)

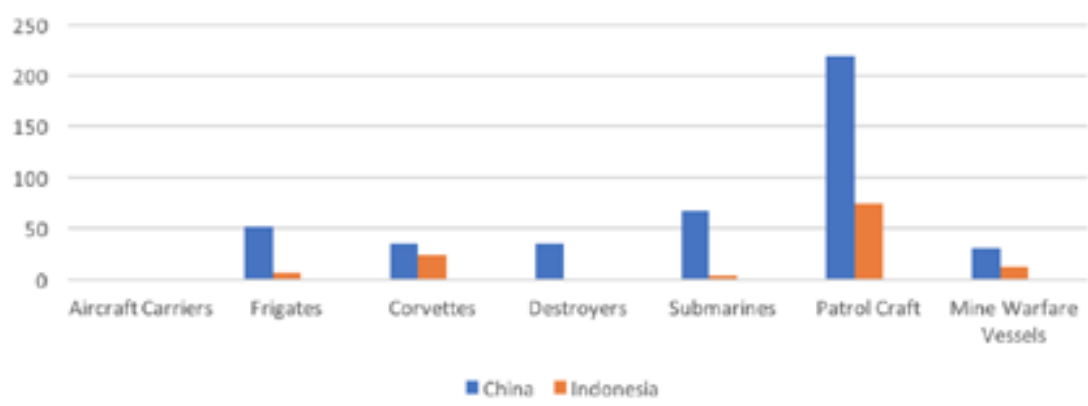

Eigur 2. Perbandingan kenemilikan alutsista angkatan laut Tioogkok dan Indonesia (2017) -

Gambar 3. Perbandingan kepemilikan alutsista angkatan darat Tiongkok dan Indonesia (2017)

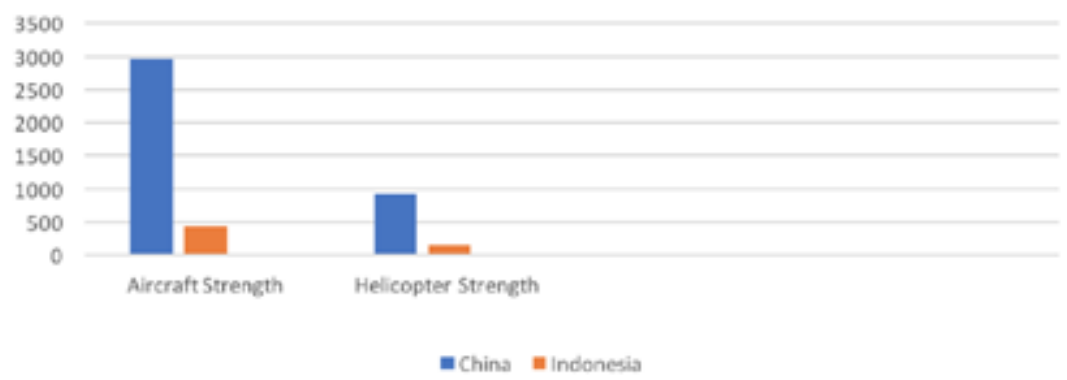

Eigur 4. Rerbandingan kencmilikan alutsista anskatan udara Tiongkek dan Indonesia (2017) -

Gambar 3. Perbandingan kepemilikan alutsista angkatan darat Tiongkok dan Indonesia (2017)

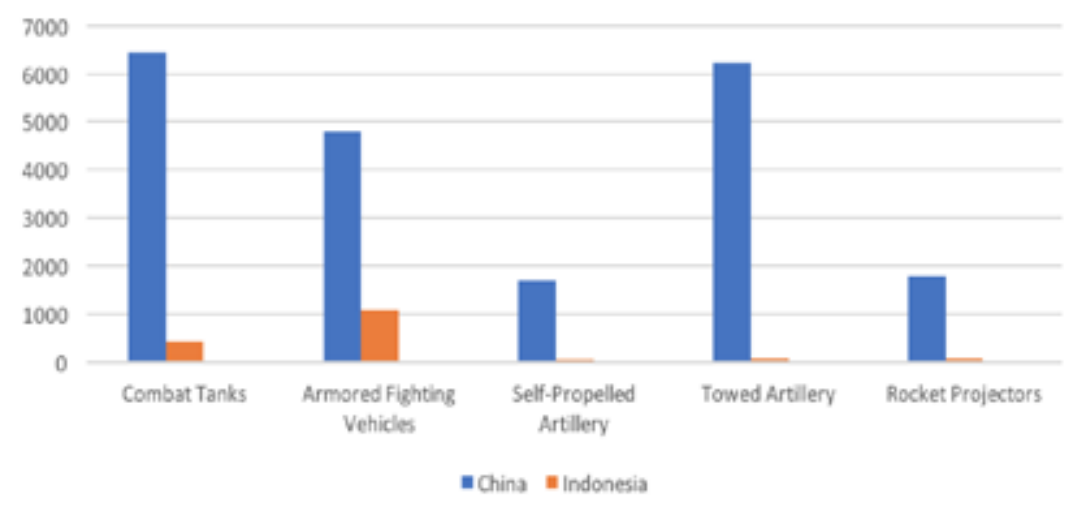

Eigur 3. Perbandingan kenemilikan alutsista angkatan darat Tiongkek dan Indonesia (2017) - 
Dari data di atas, dapat dipahami bahwa terdapat perbadi kekuatan yang cukup jauh. Apalagi dalam hal pengaruh politik Indonesia, dibandingkan dengan Tiongkok, belum mencapai pada titik pengaruh secara global sehingga menyebabkan stigma 'ancaman' dari Tiongkok pada Indonesia. Diasumsikan bahwa ketika Indonesia pada akhirnya mengambil keputusan untuk memilih posisi tegas untuk melawan Tiongkok, maka akan menimbulkan cara pandang global baru terhadap Indonesia. Hal ini menjadi problematik karena Indonesia terikat secara langsung dengan ASEAN. Sedangkan, ASEAN secara keseluruhan pun memiliki signifikansi terhadap political influence yang dimiliki Indonesia sehingga membuat posisi Indonesia yang tidak berpihak pada ASEAN pun dapat memengaruhi status politik Indonesia di wilayah regional.

Hal terakhir yang dapat merasionalkan pilihan ini adalah dorongan secara tidak langsung oleh Amerika Serikat kepada Indonesia melalui pidato yang dilontarkan oleh Presiden Barack Obama dalam forum-forum yang memiliki relasi langsung terhadap Indonesia. Dalam beberapa pidatonya Barack Obama berpendapat bahwa sebagai pihak yang cukup memegang posisi strategis atau bahkan 'leadership' di ASEAN, sudah seharusnya Indonesia turut menjadi pihak yang mengecam atau setidaknya melakukan sesuatu terhadap perilaku Tiongkok tersebut (Shekhar dan Liow, 2014). Sebagaimana yang kita tahu, Indonesia selama ini memiliki hubungan yang cukup baik dengan kedua negara. Maka ada baiknya bagi para pengambil keputusan di Indonesia untuk memilih kebijakan dengan sangat berhati. Atas dasar-dasar tersebut penulis berargumen bahwa kebijakan Indonesia yang diambil yakni memberi penamaan Laut Natuna Utara tanpa merespons dan melibatkan diri secara langsung dalam kontestasi Laut Cina Selatan merupakan satu satunya opsi yang terbaik bagi Indonesia saat ini. Hal ini sejalan dengan pendapat Breuning (2007) mengenai middle power dimana negaranegara tersebut tidak seperti negara dengan small power yang harus berpihak pada kekuatan yang lebih besar demi mempertahankan eksistensinya. Namun Indonesia belum memiliki pengaruh sebesar Great Power untuk memengaruhi politik suatu negara sehingga memiliki kecenderungan untuk menyesuaikan dan mencari jalan tengah. 


\section{Simpulan}

Dari paparan di atas dapat disimpulkan bahwa terdapat perbedaan kebijakan dan tindakan Indonesia yang cukup drastis dalam menghadapi dua kasus yang berbeda oleh negara yang berbeda pula. Jika merujuk pada teori yang dikemukakan oleh Breuning, perbedaan dua perilaku tersebut terbilang rasional. Hal ini karena dalam lingkungan internasional yang bersifat anarki, Indonesia pada saat ini diklasifikasikan sebagai negara berkekuatan Middle Power. Hal ini berarti bahwa Indonesia memiliki tingkat kebebasan untuk menentukan kebijakannya dengan baik namun terbatasi oleh perilaku negara yang memiliki klasifikasi 'great power' atau bahkan 'super power'. Namun hal ini tidak berarti bahwa Indonesia harus mengikuti kehendak negara besar tersebut karena pada dasarnya negara 'middle power' memiliki opsi yang lebih luas dan dapat memilih untuk bermain di tengah. 


\section{Daftar Pustaka}

\section{Buku}

Breuning, Marijke, 2007. Foreign Policy Analysis: A Comparative Introduction. New York: Palgrave Mcmililan.

\section{Internet}

Antara News, 2016. Natuna Islands indisputably belong to Indonesia: Foreign minister [Online]. http:/ / www.antaranews. com/en/news/102388/natuna-islands-indisputably belong-toindonesia-foreign-minister. [diakses 19 Oktober 2017]

Detik Finance, 2014. Menteri Susi: Kerugian Akibat Illegal Fishing $\mathrm{Rp} 240$ Triliun [Online]. https://finance.detik.com/beritaekonomi-bisnis/2764211/menteri-susi-kerugian- akibat-illegalfishing-rp-240-triliun .[diakses 19 Oktober 2017].

Dharanindra, Clay Vulcano. 2016. Mempertanyakan Kebijakan Penenggelaman Kapal Asing. Pusat Studi Sosial Asia Tenggara Universitas Gadjah Mada [Online]. http://pssat.ugm.ac.id/ $\mathrm{id} / 2016 / 03 / 24 /$ mempertanyakan-tindakan-penenggelamankapal-asing/. [diakses 18 oktober 2017]

Food and Agriculture Organization, 2014. Fishery and Aquaculture Country Profiles: The Republic of Indonesia [Online]. http:// www.fao.org/fishery/facp/IDN/en\#CountrySector-Overview . [diakses 19 Oktober 2017].

Global Fire Power, 2017. Indonesia Military Strength: Current Military Capabilities and Available Firepower for the Nation of Indonesia [Online]. https://www.globalfirepower.com/ country-military-strength- detail.asp?country_id=indonesia. [diakses 22 Oktober 2017].

Global Fire Power, 2017. China Military Strength: Current Military Capabilities and Available Firepower for the Nation of China [Online]. https://www.globalfirepower.com/countrymilitary-strength- detail.asp?country id=china . [diakses 22 Oktober 2017].

Hua Chunying, 2016. Foreign Ministry Spokesperson Hua Chunying's Remarks on Indonesian Navy Vessels Harassing and Shooting Chinese Fishing Boats and Fishermen [Online] http: //www.fmprc.gov.cn/mfa eng/xwfw 665399/ s2510 665401/2535 665405/t1373402.shtml. [diakses 20 Oktober 2017].

Kusumadewi, Anggi, 2016. TNI AL Beber Kronologi Tembaki Kapal 
China di Natuna [Online]. https://www.cnnindonesia.com/ nasional/20160620133053-20-139466/tni-al- beber-kronologitembaki-kapal-china-di-natuna/ . [diakses 20 Oktober 2017].

Kusumadewi, Anggi, 2016. Perairan Natuna, 'Medan Tempur' Indonesia-China [Online]. https://www.cnnindonesia.com/ nasional/20160620170157-20-139564/perairan- natuna-medantempur-indonesia-china/ . [diakses 19 Oktober 2017].

Kuwado, Fabian Januarius, 2017. Lagi, 81 Kapal Pencuri Ikan Ditenggelamkan di Penjuru Indonesia [Online]. http:/ / nasional. kompas.com/read/2017/04/01/12003881/lagi.81.kapal. pencuri.ikan.ditenggelamkan.di.penjuru.indonesia . [diakses 19 Oktober 2017].

Kwok, Yenni, 2016. Indonesian President Jokowi Visits the Natuna Islands to Send a Strong Signal to China [Online]. http://time. com/4379401/indonesia-china-jokowi-natuna- sovereigntymaritime-fishing-dispute/ . [diakses 20 Oktober 2017].

Luu et al, 2017. Beijing Criticizes Indonesia renaming part of South China Sea [Online]. http://edition.cnn.com/2017/07/15/ asia/indonesia-south-china-sea-territorial- claims/index.html . [diakses 20 Oktober 2017].

Nugroho, Bagus Prihantoro, 2016. Besok Jokowi ke Natuna, Hadiri Rangkaian HUT TNI dan Latihan Militer [Online]. https:// news.detik.com/berita/d-3314367/besok-jokowi-ke-natunahadiri-rangkaian-hut-tni-dan-latihan-militer . [diakses 19 Oktober 2017].

Nugroho, Bagus Prihantoro, 2017. Jokowi Saksikan Latihan Peran TNI di Natuna [Online]. https://news.detik.com/ berita/d-3505559/jokowi-saksikan-latihan-perang-tni-dinatuna . [diakses 19 Oktober 2017].

Nurhasim, Ahmad, 2014. Pidato Jokowi: Sudah Lama Kita Memunggungi Laut [Online]. https://nasional.tempo.co/ read/615707/pidato-jokowi-sudah-lama-kita-memunggungilaut. [diakses 19 Oktober 2017].

Pratomo, Harwanto Bimo, 2017. Pemerintah Ganti Nama Laut China Selatan jadi Laut Natuna Utara [Online]. https:// www.merdeka.com/uang/pemerintah-ganti-nama-laut-chinaselatan-jadi-laut-natuna-utara.html. [diakses 20 Oktober 2017].

Santikajaya, Awidya. 2013. Emerging Indonesia and its Global Posture [Online]. East Asia Forum.http://www.eastasiaforum. org/2013/03/07/emerging-indonesia-and-its-global- posture/ . [diakses 23 oktober 2017]. 
Sekhar, Vibanshu \& Liow, Joseph Chiyong. 2014. Indonesia as a Maritime Power: Jokowi's Vision, Strategies, and Obstacles Ahead [Online]. Brookings.edu. https://www.brookings. edu/articles/indonesia-as-a-maritime-power-jokowis-visionstrategies-and-obstacles-ahead/. [diakses 22 Oktober 2017].

Setiawan, Alfurkon, 2014. President Jokowi, in His First Speech Ensures that People Will Really Feel Government's Services [Online]. http://setkab.go.id/en/president-jokowi- in-hisfirst-speech-ensures-that-people-will-really-feel-governmentsservices/ [diakses 20 Oktober 2017]

Widhiarto, Hasyim, 2014. Jokowi Declares War on Illegal Fishing [Online]. http://www.thejakartapost.com/news/2014/11/18/ jokowi-declares-war-illegal- fishing.html. [diakses 20 Oktober 2017] 